\title{
Perbedaan Kadar Hemoglobin pada Kelompok Wanita Vegetarian dengan Non Vegetarian
}

\author{
Anak Agung Alit Pramartha \\ Program Studi Pendidikan Dokter, Fakultas Kedokteran Universitas Udayana
}

Diterima: 1 Juni 2016. Disetujui: 7 Juni 2016. Diterbitkan: Agustus 2016

\begin{abstract}
ABSTRAK
Anemia merupakan kondisi dimana kadar hemoglobin $(\mathrm{Hb})$ dalam darah di bawah normal. Anemia masalah kesehatan global karena dapat menyebabkan debilitas kronik yang berdampak besar terhadap kesehatan. Banyak masyarakat berasumsi bahwa pola makan vegetarian dapat menyebabkan anemia. Tujuan penelitian ini adalah untuk mengetahui perbedaan rerata $\mathrm{Hb}$ antara wanita yang vegetarian dengan non vegetarian.

Penelitian ini merupakan studi observasional dalam bentuk cross sectional yang melibatkan 100 sampel yang terdiri dari; 50 orang vegetarian dan 50 orang non vegetarian. Sampel dipilih dengan teknik kluster. Pengumpulan data melalui kuisioner dan pemeriksaan darah. Data yang dikumpulkan meliputi; karakteristik responden dan kadar $\mathrm{Hb}$, dan dianalisa melalui uji-t proporsi. Dari hasil uji tersebut diperoleh nilai $\mathrm{p}=0,966$ dimana $\mathrm{p}>0,05$ yang berarti tidak ada perbedaan rerata $\mathrm{Hb}$ antara wanita vegetarian dengan non vegetarian. Adapun rerata $\mathrm{Hb}$ untuk kelompok vegetarian adalah 13,77 sementara pada kelompok non vegetarian adalah 14,07. Disimpulkan bahwa tidak terdapat perbedaan signifikan rerata $\mathrm{Hb}$ antara kelompok wanita vegetarian dengan non vegetarian.
\end{abstract}

Kata Kunci : hemoglobin, wanita, vegetarian

\section{PENDAHULUAN}

Anemia merupakan masalah kesehatan global yang dialami baik negara berkembang maupun negara maju di seluruh belahan dunia. Kelainan ini merupakan penyebab debilitas kronik yang berdampak besar terhadap kesejahteraan sosial dan ekonomi, serta kesehatan fisik (WHO, 2002). Adapun penyebab anemia tersering, baik di klinik maupun di lapangan adalah gangguan metabolisme besi yang disebabkan oleh defisiensi besi (Bakta, 2007).

Anemia adalah keadaan dimana massa eritrosit dan atau massa hemoglobin yang beredar tidak dapat memenuhi fungsinya untuk menyediakan oksigen bagi jaringan tubuh. Adapun hemoglobin $\mathrm{Hb}$ merupakan suatu protein yang berfungsi sebagai alat angkut oksigen. Batas $\mathrm{Hb}$ sangat dipengaruhi oleh: umur, jenis kelamin, ketinggian tempat tinggal dari permukaan laut, dan lain-lain. Adapun kriteria anemia pada wanita dewasa tidak hamil menurut WHO adalah $\mathrm{Hb}<12 \mathrm{~g} / \mathrm{dl}$ (Bakta, 2009).

Sejumlah penelitian menunjukkan bahwa anemia defisiensi besi (ADB) berdampak negatif terhadap perkembangan kognitif dan fisik anak, serta kinerja fisik - terutama produktivitas kerja pada orang dewasa (WHO, 2001). Atmojo (dalam Wisnawa, 2012) melaporkan $A D B$ pada anak usia sekolah menyebabkan gangguan perkembangan kognitif, motorik, dan prestasi belajar. Kekurangan besi pada anak usia sekolah bisa menyebabkan perubahan tingkah laku disertai dengan rendahnya motivasi untuk menyelesaikan tugas-tugas yang bersifat intelektual. Tentu semua ini berdampak buruk pada pembangunan nasional karena mengakibatkan rendahnya kualitas sumber daya manusia Indonesia.

Banyak negara di belahan dunia mengalami kesulitan untuk menanggulangi permasalahan ABD (Bakta, 2008). World Heatlh Organization (2005) memperkirakan terdapat 1,62 miliar orang di dunia atau $24,8 \%$ dari total populasi di seluruh dunia menderita anemia. Prevalensi tertinggi ada pada kelompok anak usia pra-sekolah $(47,4 \%)$, sementara prevalensi terendah ada pada kelompok laki-laki usia dewasa (12,7\%). Meskipun demikian angka tertinggi untuk jumlah individu yang menderita anemia ternyata dimiliki oleh kelompok wanita tidak hamil, yakni sebanyak 468.4 juta orang. 
Di Indonesia, gambaran prevalensi ADB diungkapkan oleh Bakta (2007) sebagai berikut; laki-laki dewasa $16-50 \%$, wanita tidak hamil 25$48 \%$, wanita hamil $46-92 \%$. Angka prevalensi ini tinggi karena sebagian besar kasus anemia bersifat asimtomatik sehingga tidak disadari oleh penderita dan kurang mendapat perhatian serta dilewati oleh para dokter di praktek klinik.

Sejumlah penelitian telah mempelajari hubungan antara asupan nutrisi dengan status anemia. Mekipun penyebab anemia tersering pada orang dewasa adalah kehilangan eritrosit akibat pendarahan kronis, namun sesungguhnya penyebab anemia yang terpenting dan paling mudah dikendalikan adalah anemia gizi yang disebabkan oleh kekurangan zat besi, vitamin $\mathrm{B}_{12}$, dan asam folat, dan paling banyak terkandung pada makanan hewani. Sehingga ada paradigma yang berkembang di masyarakat bahwa orang yang pantang mengkonsumsi makanan hewani populasi vegetarian berisiko tinggi untuk menderita anemia.

Meskipun demikian, tidak sedikit jumlah orang yang menjadi vegetarian dengan berbagai dasar pertimbangan seperti; demi nutrisi dan kesehatan, demi lingkungan, agama, kepentingan spiritual dan kemanusiaan. Zemanta (2009) menyebutkan, banyak yang meyakini bahwa dengan menjadi vegetarian maka akan lebih aman dari penyakitpenyakit mematikan, seperti jantung koroner dan stroke. Karena diet vegetarian rendah kolesterol dan tidak berbahaya bagi tubuh.

Namun beberapa studi melaporkan dampak buruk dari pola makan vegetarian terhadap kesehatan. Vegetarian dapat menyebabkan kebutuhan nutrisi tidak terpenuhi secara memadai sehingga mengakibatkan anemia, pertumbuhan yang buruk, rakhitis, gangguan kinerja kognitif, kebutaan, defisit neuromuskuler dan akhirnya, bahkan kematian (Murphy, 2003).

Di Bali, penelitian mengenai kadar hemoglobin pada populasi vegetarian sejauh pengetahuan penulis masih sangat minim. Sementara jumlah populasi yang menjalani pola hidup vegetarian semakin bertambah, baik karena alasan kesehatan, spiritual, dan lainnya. Wanita sebagai kelompok populasi berisiko mengalami anemia defisiensi besi akibat intake zat besi yang kurang ditambah pendarahan yang dialami selama haid, membutuhkan informasi mengenai dampak pola makan yang dijalaninya terhadap kesehatan. Latar belakang tersebut mendorong penulis untuk mengkaji lebih lanjut masalah anemia dan pola makan vegetarian secara ilmiah. Tujuan penelitian ini adalah untuk mengetahui perbedaan rerata $\mathrm{Hb}$ antara wanita yang vegetarian dengan non vegetarian.

\section{METODE PENELITIAN}

Penelitian ini merupakan studi observasional dalam benttuk cross sectional dengan tahap deskriptif dan analitik. Dalam tahap deskriptif, dilakukan pengumpulan data dan analisis deskriptif mengenai kadar $\mathrm{Hb}$ pada wanita vegetarian dan non vegetarian. Pada tahap analitik dilakukan analisis komparasi untuk mengetahui perbedaan kadar $\mathrm{Hb}$ antara wanita vegetarian dan non vegetarian.

\section{Variabel Penelitian}

Variabel yang akan diteliti dalam penelitian ini adalah sebagai berikut:

1. Variabel Tergantung : Kadar $\mathrm{Hb}$

2. Variabel Bebas : Pola makan vegetarian

\section{Definisi Operasional}

Sebagai definisi operasional variabel, $\mathrm{Hb}$ (hemoglobin) adalah suatu protein yang berfungsi sebagai alat angkut oksigen yang diukur dengan alat $\mathrm{Hb}$ meter (Dr.Family ${ }^{\circledR}$ ). Vegetarian adalah pola makan yang sama sekali tidak mengkonsumsi daging, dengan atau tanpa susu (dan olahannya), keju, mentega, telur atau madu, dan paling tidak selama 3 tahun terakhir.

\section{Populasi dan Sampel}

Populasi target adalah wanita di Kota Denpasar, sedangkan populasi terjangkau adalah populasi target yang datang ke Ashram Brahma Kumaris Denpasar (salah satu sentral komunitas vegetarian di Kota Denpasar), serta populasi target yang peneliti temui saat pemeriksaan $\mathrm{Hb}$ (donor darah) di PMI Sanglah, pada rentang waktu OktoberDesember 2015.

Sampel yang akan dijadikan responden dalam penelitian ini harus memenuhi :

a. Kriteria inklusi : wanita berusia 17 tahun ke atas, tidak hamil, tidak sedang haid, tidak sedang menderita penyakit kronis, gangguan 
hemolisis, hematuria, hemoptoe, dan bersedia menjadi sampel dalam penelitian ini.

b. Kriteria eksklusi: apabila responden menderita anemia namun sedang mengkonsumsi suplemen penambah darah, dan responden tidak kooperatif selama penelitian berlangsung.

Adapun besar sampel dalam penelitian ini ditentukan dengan menggunakan rumus dari Lemenhow, dkk. (1997) dan mengacu pada penelitian tentang vegetarian sebelumnya (Wisnawa, 2012), dimana diperoleh jumlah sampel sebanyak 42 orang pada masing-masing kelompok (vegetarian dan non vegetarian). Atas dasar pertimbangan eksklusi maka jumlah keseluruhan sampel dalam penelitian ini ditentukan sebanyak 100 orang dan diambil dengan cara cluster.

\section{Pengumpulan Data}

Pengumpulan data dilakukan dengan pengisian kuisioner dan pemeriksaan Hb. Kusioner dilakukan untuk mengetahui identitas dan karakteristik sampel (nama, umur, pendidikan, pekerjaan, tingkat sosial ekonomi, keterangan vegetarian/non, lama vegetarian). Pemeriksaan kadar $\mathrm{Hb}$ dilakukan dengan menggunakan alat rapid test (Family $\mathrm{Dr}^{\circledR}$, St. Ingbert, Jerman).

\section{Analisis Data}

Data yang terkumpul dianalisis menggunakan program IBM SPSS Statistics 23, dengan Independent T-Test, untuk mengetahui perbedaan rerata $\mathrm{Hb}$ antara wanita vegetarian dan yang non vegetarian.

\section{Hipotesis Penelitian}

Hipotesis penelitian ini, $\mathrm{H}_{0}$ : tidak ada perbedaan rerata $\mathrm{Hb}$ antara wanita yang vegetarian dan yang non vegetarian. $\mathrm{Ha}$ : ada perbedaan $\mathrm{Hb}$ antara wanita yang vegetarian dan yang non vegetarian.

\section{Penarikan Simpulan}

Dalam T-Test tersebut, $\mathrm{H}_{0}$ diterima jika kemungkinan hipotesis ini benar lebih dari 5\% ( $p>$ $0,05)$. Artinya, tidak ada perbedaan rerata $\mathrm{Hb}$ antara wanita vegetarian dengan non vegetarian.

\section{HASIL PENELITIAN}

Dari 100 sampel penelitian yang terdiri dari 50 sampel vegetarian dan 50 sampel non vegetarian, terdapat esklusi sebanyak 3 orang dalam kelompok vegetarian karena responden tidak kooperatif, rata-rata usia responden adalah 49,6 tahun (standar deviasi 10,47), rata-rata $\mathrm{Hb}$ responden adalah 13,92 g/dl (standar deviasi 1,49). Data kemudian dianalis dengan melakukan uji normalitas dan homogenitas terlebih dahulu.

Uji normalitas dilakukan menggunakan program IBM SPSS Statistics 23, dengan Test Shapiro-Wilk, diperoleh nilai signifikansi untuk kelompok vegetarian adalah $p=0,754$ dan kelompok non vegetarian adalah $p=0,976$. Karena nilai signifikansi kedua kelompok lebih besar dari $p>$ 0,05 maka dapat disimpulkan bahwa data kadar hemoglobin berdistribusi normal.

Uji homogenitas dilakukan menggunakan program IBM SPSS Statistics 23, dengan Test One Way Anova, diperoleh nilai signifikansi $p=0,330$ dimana p > 0,05 maka dapat disimpulkan bahwa subyek penelitian memiliki varian homogen.

Berdasarkan hasil uji normalitas dan uji homogenitas tersebut, data berdistribusi normal dan homogen sehingga uji statistik parametrik yang tepat digunakan adalah Independent T-Test. Dari hasil uji tersebut diperoleh nilai $p=0,966$ dimana $p>0,05$ yang berarti tidak ada perbedaan rerata $\mathrm{Hb}$ antara wanita vegetarian dengan non vegetarian. Adapun rerata $\mathrm{Hb}$ untuk kelompok vegetarian adalah 13,77 g/dl (standar deviasi1,61) sementara pada kelompok non vegetarian adalah $14,07 \mathrm{~g} / \mathrm{dl}$ (standar deviasi 1,37).

\section{PEMBAHASAN}

Banyak spekulasi yang mengatakan wanita sebagai kelompok populasi berisiko mengalami anemia defisiensi besi, terlebih jika mereka menjalani pola makan vegetarian. Hasil penelitian ini tidak mendukung temuan tersebut. Meskipun secara umum diyakini bahwa wanita lebih beresiko mengalami anemia akibat pendarahan yang dialami selama haid, secara keseluruhan $\mathrm{Hb}$ responden menunjukkan rerata $\mathrm{Hb}$ adalah 13,92 $\mathrm{g} / \mathrm{dl}$ (standar deviasi 1,49 g/dl).

Pada dasarnya vegetarian adalah pola makan yang tidak mengkonsumsi produk hewani. Namun ada berbagai jenis vegetarian, mulai dari Vegan yang merupakan vegetarian murni dan hanya mengkonsumsi biji-bijian, kacang-kacangan, sayur- 
mereka mampu memenuhi nutrisi yang diperlukan

sayuran, dan buah-buahan, Vegetarian Lakto yang masih mengkonsumsi susu dan hasil olahannya, Vegetarian Lakto-ovo yang masih masih mengkonsumsi susu dan telur, Vegetarian Vesco yang masih mengkonsumsi ikan, hingga Vegetarian Fluktarian yang sangat longgar masih makan daging asalkan bukan daging yang berwarna merah (Bangun,2007).

Penelitian Craig (2009) dan Saunders (2012) membuktikan bahwa diet vegetarian tidak selalu merugikan, asalkan kebutuhan nutrisi terpenuhi. Diet vegetarian yang terencana ternyata dapat memenuhi jumlah yang non-heme besi yang dibutuhkan untuk produksi eritrosit. Jika dibandingkan dengan non-vegetarian maka vegetarian tidak memiliki kecenderungan yang lebih besar untuk menderita ADB. Demikian pula kecenderungan untuk mengalami kondisi kekurangan gizi seperti asal folat dan vitamin B12 seperti penelitian yang dilakukan oleh Lee (2011). Dala studi tersebut ditemukan meskipun kelompok Vegetarian memiliki asupan zat besi, folat, dan vitamin B-12 yang sangat rendah dari sumber makanan hewani, prevalensi kekurangan gizi ini tidak berbeda dari yang non-vegetarian yang mengkonsumsi lebih besar jumlah makanan sumber hewani.

Diet yang beragam dan seimbang merupakan kunci untuk mencukupi semua nutrisi yang diperlukan untuk cadangan nutrisi yang memadai. Untuk vegetarian, zat besi dan vitamin B-12 adalah nutrisi cenderung kurang tersedia, akan tetapi defisiensi nutrisi tersebut tidak tampak dari penelitiannya. (Lee, 2011) Beberapa hal yang yang harus diperhaikan dalam diet vegetarian adalah konsumsi vitamin $\mathrm{C}$ dan faktor-faktor lain yang mampu memfasilitasi penyerapan zat besi nonheme. Bahan makanan nabati seperti gandum, kacang-kacangan, kacang-kacangan, biji-bijian, buah-buahan kering, diperkaya zat besi sereal dan sayuran berdaun hijau dapat memberikan asupan zat besi yang cukup memadai. (Saunders, 2012)

\section{SIMPULAN}

Dari penelitian ini dapat disimpulkan bahwa tidak terdapat perbedaan signifikan rerata $\mathrm{Hb}$ antara kelompok wanita vegetarian dengan non vegetarian. Studi lebih lanjut dibutuhkan untuk mengetahui pola diet kelompok vegetarian hingga untuk cadangan nutrisi yang memadai.

\section{DAFTAR PUSTAKA}

1. Antara News, edisi 28 Maret 2012. Bali Deklarasikan Hari Vegan Organik Sedunia.http://www.antaranews.com/berita/1 301212862/bali dekIrasi- kan- hari-veganorganik-dunia (diunduh, 20 September 2012)

2. Bakta, IM. 1993. Infeksi Cacing Tambang pada Orang Dewasa dan Perannya sebagai Salah Satu Penyebab Anemia Defisiensi Besi: Studi Imunoepidemiologik di Desa Jagapati, Bali. (Disertasi). Denpasar. Universitas Udayana.

3. Bakta, IM. 2007. Hematologi Ringkas. Jakarta. Penerbit Buku Kedokteran EGC.

4. Bakta, IM. 2009. Pendekatan terhadap Pasien Anemia. Aru W. Sudoyo, dkk. (editor): Buku Ajar IImu Penyakit Dalam Jilid II Edisi IV. Jakarta.FK UI.

5. Bangun, AP. 2003. Vegetarian : Pola Hidup Sehat Berpantang Daging. Jakarta: PT Agromedia Pustaka.

6. Craig WJ, Mangels AR. 2009. Iron Status in Vegetarians. Position of the American Dietetic Association: vegetarian diets.J Am Diet Assoc 2009; 109: 1266-1282.

7. Elmadfa, I and Singer, I. 2009. Vitamin $B_{12}$ and Homocysteine Status among Vegetarian: A Global Perspective. Am J Clin Nutr 2009; 89 (suppl): 1693S-8S. Printed in USA. American Society for Nutrition.

8. Harian Kompas, edisi 28 Maret 2011. Hari Bersejarah bagi Bali dan Dunia: Deklarasi Penyelematan Bumi. http://green.kompas.com/iklim/2011/ 03/28/hari-bersejarah-bagi-bali-dan-duniadeklarasi-penyelamatan-bumi/ (diunduh, 20 September 2012)

9. Lemenhow, dkk. 1997. Besar Sampel dalam Penelitian Kesehatan. Penyunting: Kusnanto $\mathrm{H}$. Yogyakarta. Gadjah Mada University Press.

10. Lutfi. 2012. Faktor Risiko Kejadian Anemia Defisiensi Besi pada Remaja Puteri SMP di Kota Denpasar. (Tesis) Denpasar. Universitas Udayana.

11. Lee, $Y$ and Krawinkel, $M$. The nutritional status of iron, folate, and vitamin B-12 of Buddhist vegetarians. Asia Pac J Clin Nutr 2011;20 (1):4249

12. Murphy, SP. And Allen, LH. 2003. Nutritional Importance of Animal Source Foods. J. Nutr. 133: 3932S-3935S, 2003.

13. Nugraha, BA. 2005. Strategi Jitu Memilih Metode Statistik Penelitian dengan SPSS. Yogyakarta. Penerbit Andi Yogyakarta. 
14. Saunders, AV. Craig, Winston J. 2012. Iron and vegetarian diets. MJA Open 1 Suppl $2 \cdot 4$ June 2012.

15. WHO. 2001. Iron deficiency anaemia: assessment, prevention, and con-trol. A guide for programme managers. Geneva, World Health Organization.

16. WHO. 2002. The World Health Report 2002: Reducing risks, promoting healthy life. Geneva, World Health Organization.

17. WHO. 2005. Worldwide prevalence of anaemia 1993-2005 WHO Global Database on Anaemia. Geneva, World Health Organization.

18. Wisnawa, IMB. 2012. Perbedaan Asupan Zat Besi dan Protein dan Hubungannya dengan Kadar Feritin Serum dan Hemoglobin pada Remaja Vegetarian dan Non Vegetarian di Kota Denpasar. (Tesis) Denpasar. Universitas Udayana.

19.Zemanta, 2009. Untung Ruginya Menjadi Vegetarian. www.caradietsehat.com (diunduh, 20 September 2012)

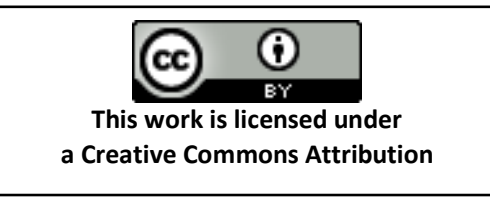

